\title{
Effect of 5-HT2A receptor antagonism on levels of D2/3 receptor occupancy and adverse behavioral side-effects induced by haloperidol: a SPECT imaging study in the rat
}

\author{
Stergios Tsartsalis $\mathbb{D}^{1,2}$, Benjamin B. Tournier ${ }^{1}$, Yesica Gloria', Philippe Millet $\mathbb{B}^{1,3}$ and Nathalie Ginovart $\mathbb{B}^{3,4}$
}

\begin{abstract}
Several studies suggested that $5-\mathrm{HT}_{2 \mathrm{~A}}$ receptor $\left(5-\mathrm{HT}_{2 \mathrm{~A}} \mathrm{R}\right)$ blockade may provide a more favorable efficacy and sideeffect profile to antipsychotic treatment. We hypothesized that a combined haloperidol (a $D_{2 / 3}$ receptor $\left(D_{2 / 3} R\right)$ antagonist) and MDL-100,907 (a 5-HT $2 \mathrm{~A} R$ antagonist) treatment would reverse the side effects and the neurochemical alterations induced by haloperidol alone and would potentialize its efficacy. We thus chronically treated male Mdr1a knock-out rats with several doses of haloperidol alone or in combination with a saturating dose of a MDL-100,907. Receptor occupancy at clinically relevant levels was validated with a dual-radiotracer in-vivo SPECT imaging of $D_{2 / 3} R$ and $5-\mathrm{HT}_{2 \mathrm{~A}} \mathrm{R}$ occupancy. Experimental tests of efficacy (dizocilpine-disrupted prepulse inhibition (PPI) of the startle reflex) and side effects (catalepsy, vacuous chewing movements) were performed. Finally, a second dual-radiotracer invivo SPECT scan assessed the neurochemical changes induced by the chronic treatments. Chronic haloperidol failed to reverse PPI disruption induced by dizocilpine, whilst administration of MDL-100,907 along with haloperidol was associated with a reversal of the effect of dizocilpine. Haloperidol at $0.5 \mathrm{mg} / \mathrm{kg} /$ day and at $1 \mathrm{mg} / \mathrm{kg} /$ day induced catalepsy that was significantly alleviated (by 50\%) by co-treatment with MDL-100,907 but only at $0.5 \mathrm{mg} / \mathrm{kg} /$ day dose of haloperidol. Chronic haloperidol treatment, event at doses as low as $0.1 \mathrm{mg} / \mathrm{kg} /$ day induced a significant upregulation of the $D_{2 / 3} R$ in the striatum (by over $40 \%$ in the nucleus accumbens and over $20 \%$ in the caudateputamen nuclei), that was not reversed by MDL-100,907. Finally, an upregulation of $5-\mathrm{HT}_{2 \mathrm{~A}} \mathrm{R}$ after chronic haloperidol treatment at a moderate dose only $(0.25 \mathrm{mg} / \mathrm{kg} /$ day $)$ was demonstrated in frontal cortical regions and the ventral tegmental area. Overall, a partial contribution of a $5-\mathrm{HT}_{2 \mathrm{~A}} \mathrm{R}$ antagonism to the efficacy and side-effect profile of antipsychotic agents is suggested.
\end{abstract}

\section{Introduction}

Antipsychotic medication constitutes the cornerstone of schizophrenia treatment. Antipsychotic agents are classified into typical (mainly $\mathrm{D}_{2}$ receptor, $\mathrm{D}_{2} \mathrm{R}$, antagonists with relatively low affinity for other receptors) and atypical (with

Correspondence: Stergios Tsartsalis (stergios.tsartsalis@hcuge.ch) 'Division of Adult Psychiatry, Department of Psychiatry, Geneva University Hospitals, Geneva, Switzerland

²Division of Psychiatric Specialties, Department of Psychiatry,

Geneva University Hospitals, Geneva, Switzerland

Full list of author information is available at the end of the article affinity for a wide spectrum of receptors, apart from the $\mathrm{D}_{2} \mathrm{R}$ ) (reviewed in ref. ${ }^{1}$ ). $\mathrm{D}_{2} \mathrm{R}$ antagonism is a central element of antipsychotic activity ${ }^{2}$. Indeed, for the majority of antipsychotic agents, a $\mathrm{D}_{2} \mathrm{R}$ occupancy between $65 \%$ and $80 \%$ of the total receptor pool in the striatum is associated with optimal antipsychotic efficacy. An occupancy below this level produces no antipsychotic effect, whereas a higher occupancy is associated with the appearance of-mainly-extrapyramidal side effects (EPS) ${ }^{1}$.

When compared to typical agents, atypical antipsychotics possess a lower propensity to cause EPS $^{3,4}$. This suggests

\section{(c) The Author(s) 2021}

(c) Open Access This article is licensed under a Creative Commons Attribution 4.0 International License, which permits use, sharing, adaptation, distribution and reproduction cc) in any medium or format, as long as you give appropriate credit to the original author(s) and the source, provide a link to the Creative Commons license, and indicate if changes were made. The images or other third party material in this article are included in the article's Creative Commons license, unless indicated otherwise in a credit line to the material. If material is not included in the article's Creative Commons license and your intended use is not permitted by statutory regulation or exceeds the permitted use, you will need to obtain permission directly from the copyright holder. To view a copy of this license, visit http://creativecommons.org/licenses/by/4.0/. 
that a better understanding of the mechanism of action of atypical antipsychotics could lead to the design of a more tolerable, hence, more efficient treatment of schizophrenia. Despite extensive efforts, the neurochemical and/or molecular bases of atypicality have long been a matter of debate. One popular theory proposes that a high $5-\mathrm{HT}_{2 \mathrm{~A}}$ vs. $\mathrm{D}_{2} \mathrm{R}$ occupancy is a defining characteristic of atypical antipsychotics and indeed, the majority of them has a high affinity for the $5-\mathrm{HT}_{2 \mathrm{~A}}$ receptor $\left(5-\mathrm{HT}_{2 \mathrm{~A}} \mathrm{R}\right)^{5}$. Whereas 5$\mathrm{HT}_{2 \mathrm{~A}} \mathrm{R}$ antagonism per se is not considered as conferring antipsychotic efficacy ${ }^{6}$, a combined blockade of $\mathrm{D}_{2}$ and 5$\mathrm{HT}_{2 \mathrm{~A}} \mathrm{R}$ has been proposed to be important for the efficacy and the reduced side effect liability of atypical versus typical drugs $^{1,2,7}$. The existing literature in the field is controversial and a systematic approach to the question of the implication of a $5-\mathrm{HT}_{2 \mathrm{~A}} \mathrm{R}$ antagonism in antipsychotic atypicality is needed. Indeed, many studies have assessed the effect of 5- $\mathrm{HT}_{2 \mathrm{~A}} \mathrm{R}$ antagonism in association with $\mathrm{D}_{2} \mathrm{R}$ blockade, notably by haloperidol, on a wide spectrum of behavioral paradigms of antipsychotic efficacy and side effect liability in rodents. However, in most studies, a single and, in most cases, saturating dose of haloperidol has been used $^{7-12}$. In addition, to our knowledge, no study has simultaneously assessed multiple aspects of antipsychotic efficacy and side effect profile.

In the present study, we chronically treated male rats with several doses of haloperidol alone or in combination with a saturating dose of a selective $5-\mathrm{HT}_{2 \mathrm{~A}} \mathrm{R}$ antagonist, MDL100,907 . The occupancy of $D_{2 / 3} R$ at clinically relevant levels, from subtherapeutic doses occupying $<65 \%$ of the $D_{2 / 3} R$ in the striatum, to doses within the optimal therapeutic "window" of $\mathrm{D}_{2} \mathrm{R}$ occupancy (65-80\%) and saturating, supratherapeutic doses (frequently associated to EPS), was validated using a dual-radiotracer single-photon emission computed tomography (SPECT) imaging approach to assess $\mathrm{D}_{2 / 3} \mathrm{R}$ and $5-\mathrm{HT}_{2 \mathrm{~A}} \mathrm{R}$ occupancies, simultaneously, during the same scan session ${ }^{13}$. In parallel, the effects of adding $5-\mathrm{HT}_{2 \mathrm{~A}}$ to different levels of $D_{2 / 3} R$ occupancies were investigated using a series of preclinical tests of efficacy (dizocilpine-also known as MK801-disrupted prepulse inhibition (PPI) of the startle reflex) and side effects (catalepsy, vacuous chewing movements (VCM)). Finally, a second dualradiotracer in-vivo SPECT scan was performed following a 4-week treatment period to assess neurochemical changes at the level of $\mathrm{D}_{2 / 3} \mathrm{R}$ and $5-\mathrm{HT}_{2 \mathrm{~A}} \mathrm{R}$ binding with respect to the chronic treatment regimes. Our hypothesis was that adding $5-\mathrm{HT}_{2 \mathrm{~A}} \mathrm{R}$ antagonism, a putative substrate of antipsychotic atypicality, could enhance the efficacy of haloperidol at the experimental tasks and alleviate, at least partially, EPS.

\section{Materials and methods Animals}

A total of 136 male adult Mdr1a knock-out rats (weighing 300-500 g), were used. P-glycoprotein knock- out in this strain increases the permeability of the blood-brain barrier, allowing in-vivo $5-\mathrm{HT}_{2 \mathrm{~A}} \mathrm{R}$ imaging with $\left[{ }^{125} \mathrm{I}\right] \mathrm{R} 91150$, which is impeded in wild-type animals due to the low brain absorption of this radiotracer ${ }^{13-15}$. The animals were housed at constant room temperature $\left(21 \pm 1^{\circ} \mathrm{C}\right.$ ) under a regular light/dark schedule (light 07:00-19:00). Food and water were freely available.

All experimental procedures were performed in accordance with the Swiss Federal Law and approved by the local authority on Animal Experimentation.

\section{Experimental procedures outline}

The timeline of the study is graphically presented in Fig. 1. An initial ex-vivo study was performed to determine the dose-occupancy of haloperidol and MDL100,907 at $\mathrm{D}_{2 / 3} \mathrm{R}$ and $5-\mathrm{HT}_{2 \mathrm{~A}} \mathrm{R}$, respectively, in our model. Using subcutaneously implanted osmotic minipumps, ranging doses of haloperidol and MDL-100,907 were administered (in separate groups of rats) to produce chronic and stable levels of $\mathrm{D}_{2 / 3} \mathrm{R}$ and $5-\mathrm{HT}_{2 \mathrm{~A}} \mathrm{R}$ occupancies. At the end of a 4-week treatment period, ex-vivo receptor binding measurements were performed to establish the dose-occupancy curve for haloperidol and MDL-100,907. Based on the ex-vivo $D_{2 / 3} R$ occupancy results, doses of haloperidol that achieved: (1) subtherapeutic/at the lower spectrum of the optimal occupancy window, (2) therapeutic levels of $\mathrm{D}_{2} \mathrm{R}$ occupancy (within the $65-80 \%$ occupancy window) and, (3) supratherapeutic doses associated to a side effect risk $(>80 \%$ of occupancy) ${ }^{1}$, were selected and used alone or in combination with a $5-\mathrm{HT}_{2 \mathrm{~A}} \mathrm{R}$ saturating dose of MDL-100,907. This allowed to compare, in vivo, their chronic effects both on behavioral tasks designed to assess clinical efficacy and EPS liability and on $\mathrm{D}_{2 / 3} \mathrm{R}$ and $5-\mathrm{HT}_{2 \mathrm{~A}} \mathrm{R}$ binding.

\section{Osmotic minipump implantation procedure and chronic drug treatment}

Haloperidol and MDL-100,907 (Sigma-Aldrich, Buchs, Switzerland) were diluted in a 50\% DMSO solution in $\mathrm{NaCl}$ 0.9\% (50\% v/v). MDL-100,907 was initially diluted in a few drops of a $10 \%$ acetic acid solution (constituting $<5 \%$ of the final volume of the $\mathrm{DMSO} / \mathrm{NaCl}$ solution). For both haloperidol and MDL-100,907, the doses used in the initial ex-vivo dose-occupancy curve estimation study ranged from 0 to $1 \mathrm{mg} / \mathrm{kg} /$ day. The haloperidol/MDL100,907 doses used in the subsequent in-vivo study (hereon abbreviated as $\mathrm{Hx} / \mathrm{My}$ with $\mathrm{x}$ and $\mathrm{y}$ being the dose of each drug in $\mathrm{mg} / \mathrm{kg} /$ day) and the number of rats $(n)$ in each dosage were as follows: H0/M0 $(n=12), \mathrm{H} 0.1 / \mathrm{M} 0$ $(n=8)$, H0.1/M0.5 (subtherapeutic dose of haloperidol) $(n=7)$, H0.25/M0 $(n=7)$, H0.25/M0.5 $(n=7)$ (therapeutic dose), H0.5/M0 ( $n=7), \mathrm{H} 0.5 / \mathrm{M} 0.5(n=7), \mathrm{H} 1 /$ M0 $(n=12)$, and H1/M0.5 $(n=12)$ (supratherapeutic doses). The doses employed in the in vivo study were 


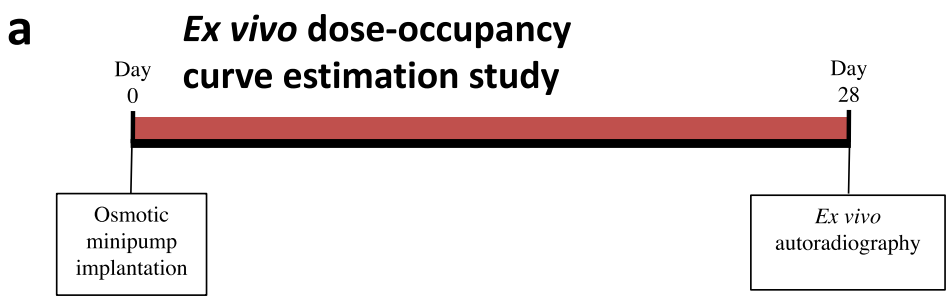

Treatment:

Haloperidol $(0-1 \mathrm{mg} / \mathrm{kg} / \mathrm{day})$ or MDL-100,907 (0-1 mg/kg/day)

b

Main (in vivo imaging) study

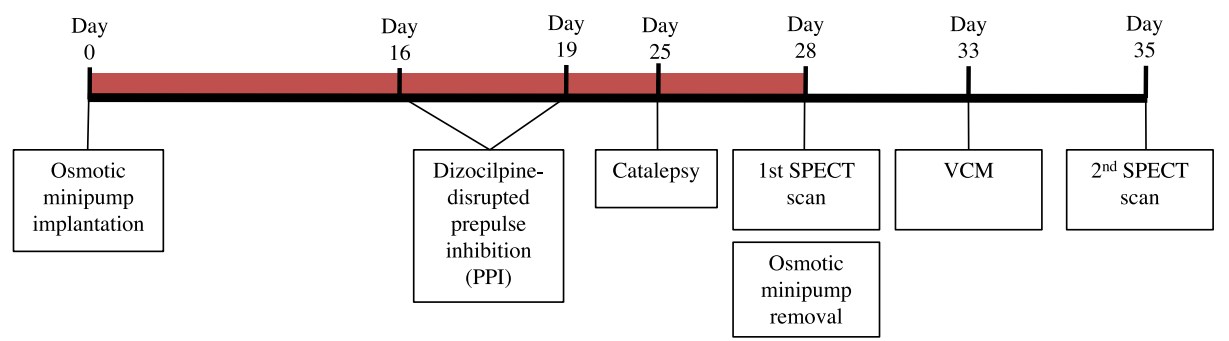

Treatment:

Haloperidol (0-1 mg/kg/day) \pm MDL-100,907 (0-0.5 mg/kg/day)

Fig. 1 Graphical presentation of the timeline of the present study. The black line represents the timeline of the experiments with the various time-points (in days) noted above the line. The red line represents the period during which the animals were under treatment. The square boxes below the black line describe the behavioral and/or imaging experiments undetaken at specific time-points.

informed by the ex vivo dose-occupancy estimation study. The rats were randomly assigned into dose groups by shuffling the rat ID/dose labels. The investigators who performed the experiments were totally blinded to the group and dose assignment of rats. Investigators who analyzed the results were aware of the group-assignment but blinded to the dose assignment to each group. Exclusion criteria included signs of local (at the surgical site) and generalized infection, dehydration, rapid weight loss, and lethargy.

Osmotic minipump (2ML4, Alzet, Cupertino, CA, USA) implantation, localized between the scapulae, was performed under isoflurane anesthesia (2.5-3\%) and buprenorphine analgesia $(0.02 \mathrm{mg} / \mathrm{kg}$ sc; Temgesic, Reckitt Benckiser Pharmaceuticals Inc.). For a more detailed description, please see the supplemental materials and methods.

At the end of the 28 days treatment period, the minipumps were removed to end the chronic administration period.

\section{Behavioral testing}

The dizocilpine-disrupted PPI of the startle reflex was performed as a proxy to the therapeutic efficacy of the chronic treatment ${ }^{16-18}$, between 16 and 19 days following implantation of the osmotic minipumps. The protocol described here ${ }^{19}$ was followed, including two habituation sessions (Days 1 and 2) and a saline-pretreatment test session (Day 3). Dizocilpine $(0.15 \mathrm{mg} / \mathrm{kg})$ was injected as pretreatment on Day 4. The amplitude of startle responses was recorded in all trials. The magnitude of PPI was calculated as a percent inhibition of the startle amplitude in the pulse-alone trial ${ }^{18,20}$, using two prepulse sound volumes ( 80 and $85 \mathrm{~dB})$.

Catalepsy is indicative of the potential of a pharmacological agent to induce extrapyramidal symptoms ${ }^{1,7}$. At 25 days following minipump implantation, catalepsy was assessed over a 3-min period as described previously ${ }^{21}$ (see supplemental Materials and Methods).

VCM are purposeless, vertical jaw movements directed towards no object. They are considered a rodent model of antipsychotic drug-induced tardive dyskinesia ${ }^{1,7,11,22,23}$. The assessment of VCM took place 5 days after the removal of the osmotic minipumps, i.e. the end of the treatment period. To assess VCM, rats were placed in a plexiglass restraining tube. After $2 \mathrm{~min}$ of habituation, VCM were recorded over a period of $2 \min ^{24,25}$. 


\section{Ex-vivo receptor-binding measurements and in-vivo imaging \\ Ex-vivo estimation of receptor occupancy by haloperidol and MDL-100,907}

Preparation of $\left[{ }^{123} \mathrm{I}\right] \mathrm{IBZM}$ and $\left[{ }^{125} \mathrm{I}\right] \mathrm{R} 91150$ was performed as previously described ${ }^{13-15}$. In the ex-vivo doseoccupancy curve estimations, rats were administered with $\left[{ }^{123} \mathrm{I}\right] \mathrm{IBZM}$ and $\left[{ }^{125} \mathrm{I}\right] \mathrm{R} 91150$ to concurrently measure $\mathrm{D}_{2 /}$ ${ }_{3} \mathrm{R}$ and 5-HT2AR occupancy, respectively. At 28 days of treatment, rats were anesthetized using isoflurane anesthesia (4\% for induction, $2.5 \%$ for maintenance) and injected with $6.48 \pm 0.34 \mathrm{MBq}$ of $\left[{ }^{123} \mathrm{I}\right] \mathrm{IBZM}$ or $6.98 \pm$ $0.98 \mathrm{MBq}$ of $\left[{ }^{123} \mathrm{I}\right] \mathrm{R} 91150$ (with respect to the treatment, haloperidol or MDL-100,907, respectively). At $120 \mathrm{~min}$ post-injection, rats were euthanized by decapitation, their brain removed, and their striatum, frontal cortex, and cerebellum dissected and weighed. Radioactivity in the dissected brain regions was immediately measured in an automated gamma counting system (expressed in $\mathrm{kBq} / \mathrm{g}$ of tissue weight) for the radiotracer labeled with ${ }^{123} \mathrm{I}$. Radioactivity was decay-corrected to the time of the brain dissection.

For the ex-vivo study, the standardized uptake ratio (SUR) for each radiotracer in the striatum and the frontal cortex was measured using the radioactivity measured in the gamma counting system as follows: SUR $=$ (radioactivity in the target-region)/(radioactivity in the cerebellum) -1 . The \% occupancy $(\mathrm{O})$ of the $\mathrm{D}_{2 / 3} \mathrm{R}$ and the $5-\mathrm{HT}_{2 \mathrm{~A}} \mathrm{R}$ from their respective antagonists was estimated using the following formula: $\mathrm{O}(\%)=\left(1-\right.$ SUR/SUR $\left.\mathrm{CON}_{\mathrm{N}}\right)$ *100, where SUR corresponds to the value obtained from an individual study in which a dose of antagonist was

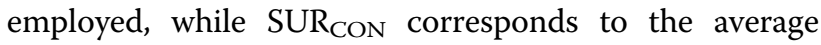
value obtained from the control animals in which no antagonist was administered.

\section{In-vivo imaging experiments}

Dual-radiotracer SPECT imaging ${ }^{13}$ was performed in the context of the main in-vivo study described in this paper to assess the level of $\mathrm{D}_{2 / 3} \mathrm{R}$ and $5-\mathrm{HT}_{2 \mathrm{~A}} \mathrm{R}$ occupancy by haloperidol and MDL-100,907, and the binding of $\mathrm{D}_{2}$ / ${ }_{3} \mathrm{R}$ and $5-\mathrm{HT}_{2 \mathrm{~A}} \mathrm{R}$ after chronic treatment with these agents. In vivo dual radiotracer SPECT was performed as described previously ${ }^{13}$. At the end of the 28-day treatment period, the first dual-radiotracer SPECT scan was performed, to measure the occupancy of the $\mathrm{D}_{2 / 3} \mathrm{R}$ and the 5 $\mathrm{HT}_{2 \mathrm{~A}} \mathrm{R}$ by their respective antagonists. One week later, an identical dual-radiotracer SPECT scan was performed to index the density of the $\mathrm{D}_{2 / 3} \mathrm{R}$ and the $5-\mathrm{HT}_{2 \mathrm{~A}} \mathrm{R}$. Rats were simultaneously injected with a mixture of $\left[{ }^{123} \mathrm{I}\right]$ IBZM $(32.7 \pm 8.2 \mathrm{MBq})$ and $\left[{ }^{125} \mathrm{I}\right] \mathrm{R} 91150(26.9 \pm 6 \mathrm{MBq})$ over $30 \mathrm{~s}$. The detailed scan procedures were exactly the same as described here ${ }^{13,15}$.
SPECT image analysis was performed as described previously $^{13}$. A volume-of-interest (VOI) template incorporated in $\mathrm{PMOD}^{26}$ was used to extract the radioactivity from each brain VOI and the cerebellum (CER), which was used as reference region. SUR values from the first (to estimate the receptor occupancies by the antagonist treatment) and the second SPECT scan (to estimate the alteration in receptors' binding due to the chronic treatment) were estimated as follows: (radioactivity in the target VOI)/(radioactivity in CER) - 1 . For the estimation of $D_{2 / 3} R$ occupancies using in-vivo imaging with $\left[{ }^{123} \mathrm{I}\right]$ IBZM, a 0.55 value was subtracted from the SUR and SUR $_{\text {CON }}$ values to account for the difference in the nondisplaceable binding between the striatum (target region) and the cerebellum (reference region) for this radiotracer $^{15}$ (please see the supplemental materials and methods for a more detailed description).

\section{Statistical analysis}

Normal distribution of data was assessed using the Shapiro-Wilk test. Post-hoc analysis was performed when appropriate. For the analysis of the PPI, as well as for the analysis of the alterations in $D_{2 / 3}$ binding, a multi-variate analysis of variance (MANOVA) was employed with haloperidol and MDL-100,907 dose as the independent factors. For non-normally distributed data, non-parametric tests (Kruskal-Wallis and Mann-Whitney) were employed. A sample size analysis with the graphical Douglas Altman's nomogram was performed $^{27}$. For $5-\mathrm{HT}_{2 \mathrm{~A}} \mathrm{R}$ binding, parametric images of SUR were compared between groups using the SPM12 software (Wellcome Trust Centre for Neuroimaging, UCL, London, UK) and the Small Animal Molecular Imaging Toolbox ${ }^{28}$ (SAMIT, Groningen, Netherlands) in Matlab (R2019, Mathworks Inc, USA). An uncorrected $p$ at 0.001 with a cluster size threshold of 100 voxels was employed ${ }^{29,30}$. All the statistical tests were two-sided. No adjustment for multiple comparisons was employed. Throughout the manuscript, "average" refers to the mean value. All experiments were performed once. All data associated with this manuscript is available upon request to the corresponding author.

\section{Results}

Occupancy of the $\mathrm{D}_{2 / 3} \mathrm{R}$ and the $5-\mathrm{HT}_{2 \mathrm{~A}} \mathrm{R}$ by haloperidol and MDL-100,907

Figure 2a, b present the dose-occupancy curves for haloperidol from the in vivo and the initial ex vivo occupancy estimations, respectively. Both in vivo and ex vivo dose-occupancy curve estimation approaches yielded similar results. For haloperidol, a $0.1 \mathrm{mg} / \mathrm{kg} /$ day dose leads to a $D_{2 / 3} \mathrm{R}$ occupancy of around $45 \%$ (Fig. 2a). A dose of $0.25 \mathrm{mg} / \mathrm{kg} /$ day leads to a $\mathrm{D}_{2 / 3} \mathrm{R}$ occupancy of a little $<80 \%$, while the doses of 0.5 and $1 \mathrm{mg} / \mathrm{kg} /$ day lead 


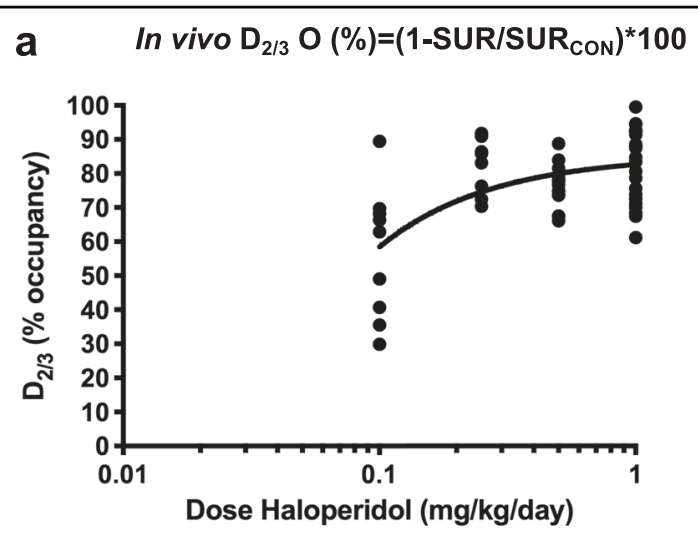

b Ex vivo $\mathrm{D}_{2 / 3}$ occupancy
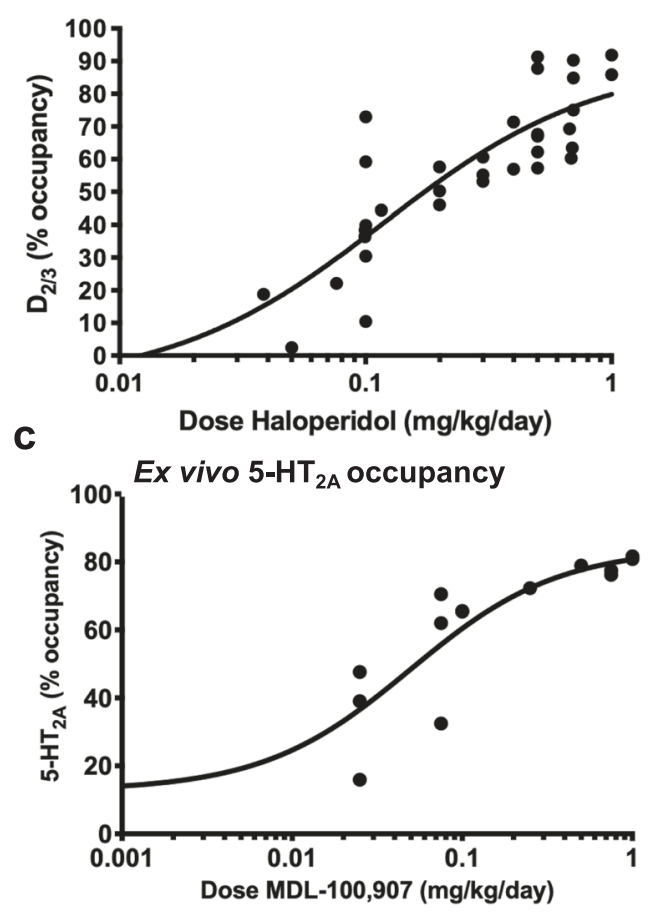

Fig. 2 Haloperidol and MDL-100,907 dose-occupancy curves. Fig. $2 a$ and $2 b$ shows the occupancy of the $D_{2 / 3} R$ in the striatum by various doses of haloperidol estimated in vivo and ex vivo, respectively. The equation used to calculate the occupancy is shown above Fig. 2a. Fig. 2c shows the occupancy of 5-HT2AR in the frontal cortex of rats by various doses of MDL-100,907, estimated ex vivo.

towards saturations of more than $85-90 \%$ of the $D_{2 / 3} R$ in the Caudate-Putamen (CP; Fig. 2a). The ex-vivo doseoccupancy curve for MDL-100,907 at frontal $5-\mathrm{HT}_{2 \mathrm{~A}} \mathrm{R}$ is shown in Fig. 2c. The MDL-100,907 dose of $0.5 \mathrm{mg} / \mathrm{kg} /$ day, which produces an almost total saturation of the frontal $5-\mathrm{HT}_{2 \mathrm{~A}} \mathrm{R}$, was subsequently employed in the in-vivo study. Haloperidol did not induce $5-\mathrm{HT}_{2 \mathrm{~A}} \mathrm{R}$ occupancy and MDL-100,907 did not induce $\mathrm{D}_{2 / 3} \mathrm{R}$ occupancy at any dose (data not shown).
Effect of chronic haloperidol and MDL-100,907 on the dizocilpine-disrupted PPI of the startle

In control animals (HOM0, neither dizocilpine nor haloperidol/MDL-100,907 treatment) the PPI (both auditory stimuli volumes combined) was, in average, $62 \%$ (Fig. 3a). As expected, dizocilpine disrupted PPI in control rats, diminishing it, in average, to $31 \%(p<$ 0.01 ). Given that the hypothesis under evaluation concerned the ability of the various combinations of haloperidol and MDL-100,907 to reverse the effect of dizocilpine on PPI, a MANOVA was performed only on the dizocilpine-treated rats, using the PPI (\%) responses after 80 (Fig. 3a) and $85 \mathrm{~dB}$ (Fig. 3b) as dependent variables and the haloperidol and MDL-100,907 doses as factors. When added to the various doses of haloperidol, a significant effect of MDL-100,907 treatment $(p<0.05)$ on dizocilpine-induced PPI disruption was observed, at least at the lowest doses of haloperidol (0.1 and $0.25 \mathrm{mg} / \mathrm{kg} /$ day). In addition, a significant interaction between the haloperidol and MDL-100,907 factors was observed $(p<0.05)$. Post hoc analysis using a protected Fischer's least significant differences (LSD) test failed to demonstrate signification differences between any of the individual haloperidol and MDL-100,907 dosage combinations and the control group.

\section{Haloperidol-induced catalepsy reversal by MDL-100,907}

Chronic haloperidol doses up to $0.25 \mathrm{mg} / \mathrm{kg} /$ day, alone or in combination with $1 \mathrm{mg} / \mathrm{kg} /$ day MDL-100,907, had no effect on catalepsy (Fig. 3c). In contrast, haloperidol doses of $0.5 \mathrm{mg} / \mathrm{kg} /$ day and $1 \mathrm{mg} / \mathrm{kg} /$ day induced a strong catalepsy, measured as the time elapsed between the placement of the animal on the grid and their first paw movements $(111.4 \pm 52.5$ and $137.8 \pm 79.1 \mathrm{~s}$ to first movement, respectively, Fig. 3c). This difference was statistically significant as revealed by a Kruskal-Wallis test, $p<0.001$ and post hoc Mann-Whitney tests $p<$ $0.05)$. Adding a $5-\mathrm{HT}_{2 \mathrm{~A}} \mathrm{R}$ antagonism alleviated the cataleptic effect of haloperidol at $0.5 \mathrm{mg} / \mathrm{kg} /$ day $(40.3 \pm$ $26.9 \mathrm{~s}, p<0.05)$ but not at $1 \mathrm{mg} / \mathrm{kg} /$ day $(122.1 \pm 92.2 \mathrm{~s}$, $p>0.05)$.

\section{Haloperidol-induced vacuous VCM}

A chronic treatment with doses of haloperidol of 0.5 and $1 \mathrm{mg} / \mathrm{kg} /$ day induced a significant increase in the number of the VCM $(18.7 \pm 5.8$ and $13.3 \pm 8.2$, respectively) when compared to vehicle-treated rats $(2.4 \pm 2.11$, Kruskal-Wallis, $p<0.001$ and Mann-Whitney test for post hoc comparisons, $p<0.05)$. Lower haloperidol doses of 0.1 and $0.25 \mathrm{mg} / \mathrm{kg} /$ day induced no VCM. On the other hand, MDL-100,907 treatment had no effect on this phenomenon, i.e. did not manage to alleviate the haloperidol-induced VCM syndrome (Fig. 3d). 

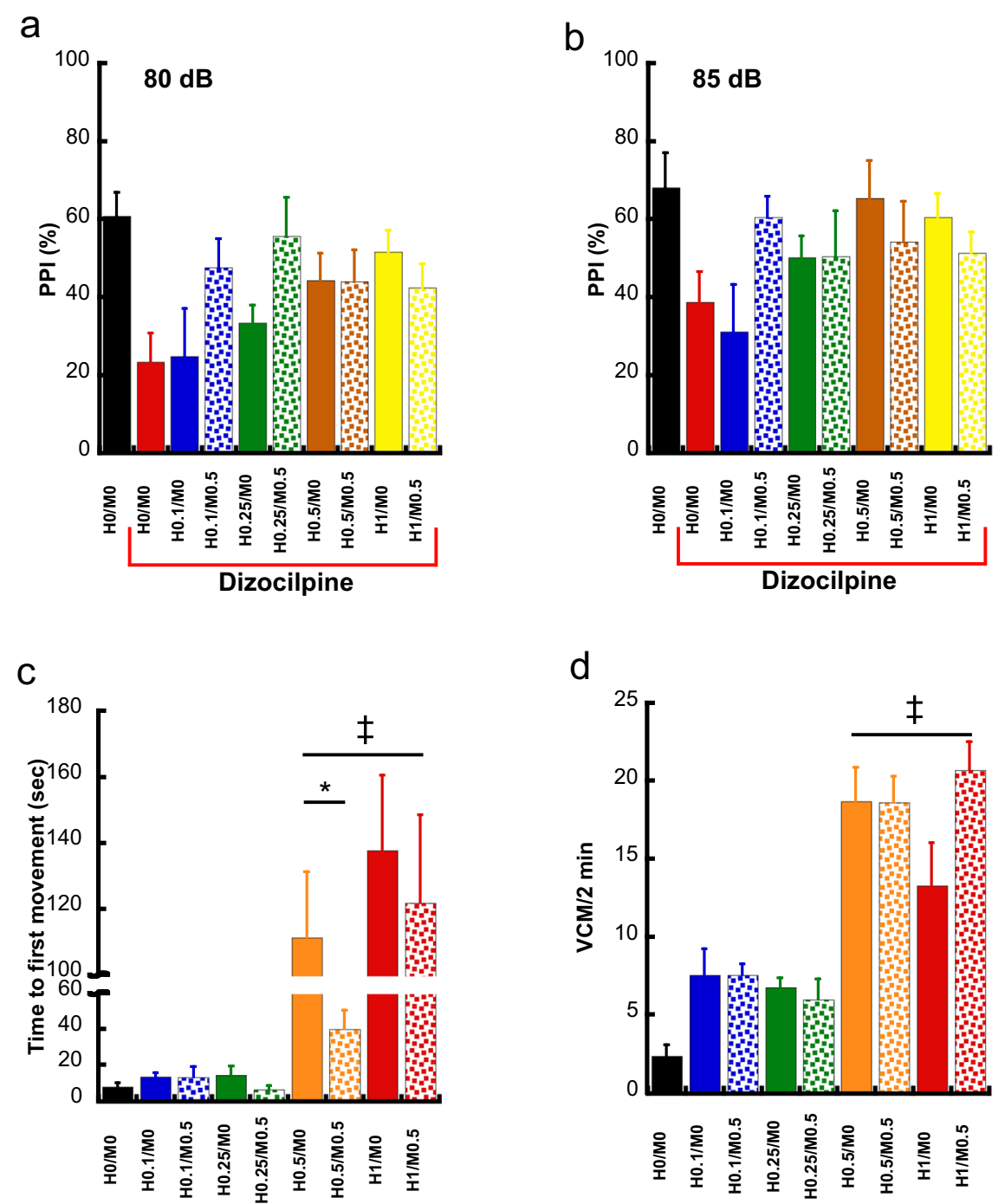

Fig. 3 Results of the behavioral tests. The effect of the various haloperidol and MDL-100,907 combinations on the disruption of the PPI by dizocilpine using a (a) $80 \mathrm{~dB}$ and a (b) $85 \mathrm{~dB}$ auditory pulse (mean \pm SEM values). The leftmost bar corresponds to the control group (HO/MO), not pre-treated with dizocilpine (baseline PPI). The rest correspond to rats pretreated with dizocilpine. The haloperidol and MDL-100,907 dosages are depicted below each bar. No significant differences were found in pairwise comparisons. c Results of the catalepsy tests under the various chronic treatment combinations (mean \pm SEM). ${ }^{\ddagger}$ Denotes significant differences between the mean time lapses between these four doses compared to the control (H0M0). *Denotes a significant difference between the H0.5MO and the H0.5/M0.5 group. d The effect of the chronic treatment with haloperidol and MDL-100,907 on the induction of VCM/2min (mean \pm SEM). ${ }^{\ddagger}$ Denotes a significant increase in the number of the VCM compared to vehicle-treated rats.

\section{Alteration in $\mathrm{D}_{2 / 3} \mathrm{R}$ and $5-\mathrm{HT}_{2 \mathrm{~A}} \mathrm{R}$ binding after chronic antagonism}

Figure $4 \mathrm{a}$ and $\mathrm{b}$ show the effect of chronic treatment with the various doses of haloperidol and MDL-100,907 on $\mathrm{D}_{2 / 3} \mathrm{R}$ binding in the $\mathrm{CP}$ and the Nucleus Accumbens (NAc), respectively. All doses of haloperidol induced a significant up-regulation of $\mathrm{D}_{2 / 3}$ binding in both regions compared to the vehicle-treated groups, as measured with $\left[{ }^{123} \mathrm{I}\right] \mathrm{IBZM}$, one week after the end of the treatment period $(p<0.001$ for the effect of haloperidol using a twoway MANOVA and significant post hoc tests of all doses against the vehicle-treated group). The addition of MDL-
100,907 had no effect on this haloperidol-induced $D_{2 / 3}$ up-regulation in either the $\mathrm{CP}$ or the NAc (Fig. 4a, b). For the analysis of $\mathrm{D}_{2 / 3} \mathrm{R}$-binding alterations, only VOI-wise analysis was performed, given that the distribution of $\left[{ }^{123} \mathrm{I}\right] \mathrm{IBZM}$ binding is restricted in the NAc and the CP. Statistical comparison of the effect of the different treatment doses on [ $\left.{ }^{125} \mathrm{I}\right] \mathrm{R} 91150$ binding was performed at the voxel level using SPM. Only the haloperidol dose of $0.25 \mathrm{mg} / \mathrm{kg} /$ day has a significant effect on $5-\mathrm{HT}_{2 \mathrm{~A}} \mathrm{R}$ binding (Fig. 5) on a collection of frontal cerebral voxels, encompassing parts of the left orbitofrontal, piriform, insular and olfactory cortex, the right piriform and 


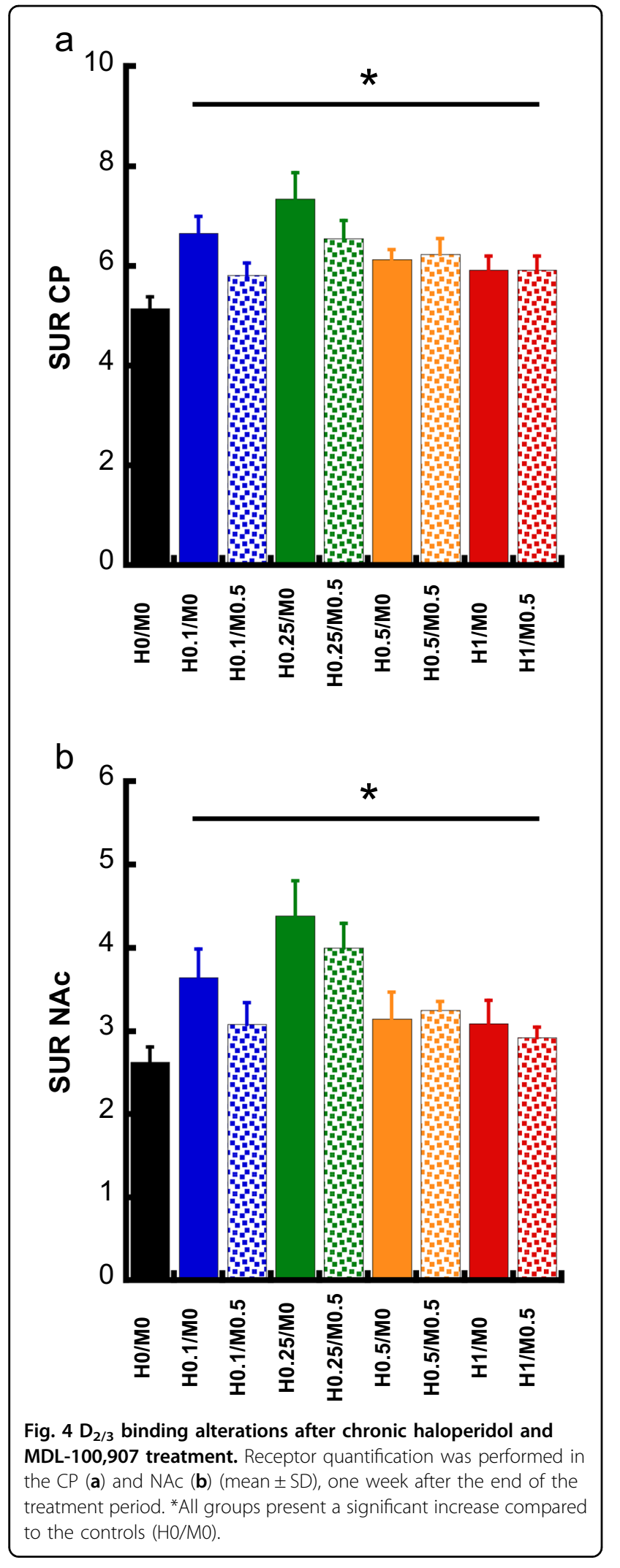

olfactory cortex as well as the left ventral tegmental area (VTA).

\section{Discussion}

Strengths of the in-vivo imaging approach and design of the study

This study described a thorough evaluation of the impact of $5-\mathrm{HT}_{2 \mathrm{~A}} \mathrm{R}$ antagonism on multiple aspects of the efficacy and side effect profile of haloperidol. It presents a certain number of strengths regarding its design, the variety of outcome measures and the methods to evaluate these outcome measures. The major strength of the present study is, to our view, the carefully chosen doses of haloperidol for the chronic treatment that were both representative of what has been employed in the literature and clinically relevant. Indeed, we employed doses ranging from relatively low $(0.1 \mathrm{mg} / \mathrm{kg} /$ day $)$ to particularly high $(1 \mathrm{mg} / \mathrm{kg} /$ day $)$. The $0.1 \mathrm{mg} / \mathrm{kg} /$ day dose is particularly interesting as it produces an occupancy of around $45-60 \%$ of the $D_{2 / 3}$ receptors in the striatum, i.e. subtherapeutic or at the lowest end of the occupancy window that is considered optimal ${ }^{1,7}$. This occupancy was confirmed both ex vivo and in vivo. The $1 \mathrm{mg} / \mathrm{kg} /$ day dose was included in this study to allow a direct comparison with the majority of previous studies in the field. As discussed in the subsequent sections of this paper, the use of a $1 \mathrm{mg} / \mathrm{kg} /$ day dose of haloperidol in the literature (which has been criticized as unreasonably high ${ }^{7}$ ) may "conceal" any ameliorative effect of co-administered agents, such as the MDL-100,907. On the contrary, the use of a $0.5 \mathrm{mg} /$ $\mathrm{kg} /$ day dose almost saturates striatal $\mathrm{D}_{2 / 3} \mathrm{R}$ (Fig. 2), induces clinically relevant side effects (e.g. catalepsy and $\mathrm{VCM}$ ) and allows to demonstrate potential ameliorative effects of MDL-100,907, that were previously unappreciated in the literature.

A chronic treatment scheme with the $\mathrm{D}_{2 / 3} \mathrm{R}$ and 5$\mathrm{HT}_{2 \mathrm{~A}} \mathrm{R}$ antagonists was chosen. This is probably more clinically relevant for the evaluation of the effects of these antagonists firstly because antipsychotic agents are almost always employed chronically in patients. Secondly, the administration of these antagonists using osmotic minipumps and not via daily injections induces a stable occupancy of the receptors over time ${ }^{31}$, resembling the temporal pattern of occupancy in patients.

\section{5- $\mathrm{HT}_{2 \mathrm{~A}} \mathrm{R}$ antagonism partially alleviates haloperidol- induced catalepsy but has no effect on VCM}

The present study confirms and extends the existing literature on the effect of a $5-\mathrm{HT}_{2 \mathrm{~A}} \mathrm{R}$ antagonism on the behavioral and neurochemical alterations induced by a $D_{2 /}$ ${ }_{3} \mathrm{R}$-specific antagonist. An interesting finding of our study concerns the effect of MDL-100,907 on haloperidol-induced 


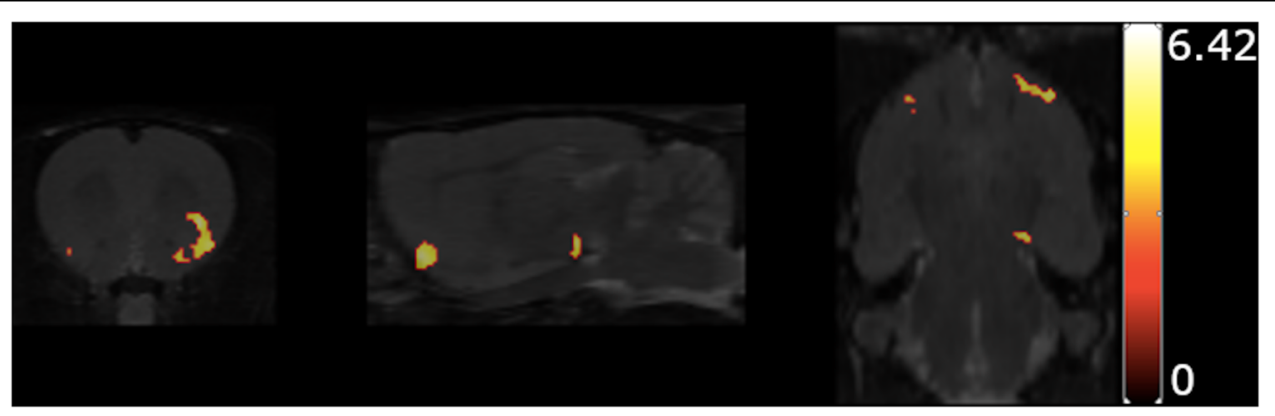

Fig. 5 Results of the voxel-wise comparison of the $5-\mathrm{HT}_{2 \mathrm{~A}} \mathrm{R}$ binding between the rats of the control group (HO/MO) and the rats treated with haloperidol at $0.25 \mathrm{mg} / \mathrm{kg} / \mathrm{day}$.

catalepsy. As expected, a high occupancy of the striatal $D_{2 /}$ ${ }_{3} \mathrm{R}$ induces this acute extrapyramidal symptom. Rats treated with the two higher haloperidol doses $(0.5$ and $1 \mathrm{mg} / \mathrm{kg} /$ day $)$ showed a striatal occupancy $>80 \%$ and presented a strong catalepsy, which confirms current literature ${ }^{8-12}$. In accordance with this literature, $5-\mathrm{HT}_{2 \mathrm{~A}} \mathrm{R}$ antagonism failed to counteract the cataleptic effect of the highest dose of haloperidol $\left(1 \mathrm{mg} / \mathrm{kg} /\right.$ day). Interestingly, $5-\mathrm{HT}_{2 \mathrm{~A}} \mathrm{R}$ antagonism managed to significantly reduce the cataleptic effect of the $0.5 \mathrm{mg} / \mathrm{kg} /$ day dose of haloperidol, a finding that, to our knowledge, has never been reported before. Indeed, previous studies which evaluated the effect of MDL-100,907 on chronic haloperidol-induced catalepsy only employed high doses of haloperidol $(1 \mathrm{mg} / \mathrm{kg} / \text { day or higher })^{8,10}$. Regarding acute treatment regimes, Creed-Carson et al..$^{10}$ employed a single subcutaneous $0.5 \mathrm{mg} / \mathrm{kg}$ dose of haloperidol. The resulting catalepsy was not reversed by a $0.5 \mathrm{mg} / \mathrm{kg}$ dose of MDL-100,907 (the exact same dose as in the present study). Similar results were observed with an acute administration of $0.63 \mathrm{mg} / \mathrm{kg}$ of haloperidol ${ }^{32}$ and MDL-100,907 at $0.1 \mathrm{mg} /$ $\mathrm{kg}$. However, this apparent discrepancy might be explained by the differential effects of an acutely vs. chronically administered dose of haloperidol and by the lower dose of MDL-100,907 employed in the latter study. Indeed, it is probable that the duration of treatment with an antagonist has an impact on the relationship between its dose and the resulting catalepsy: an acute dose of haloperidol at $0.25 \mathrm{mg} /$ $\mathrm{kg}$ induces catalepsy, while the same dose administered chronically does $\operatorname{not}^{33}$. In addition, in studies comparing a continuous vs. once daily administration of haloperidol via subcutaneous injections, it was demonstrated that the same dose of haloperidol, when administered once daily, produces steep peaks in occupancy that are considerably higher than the occupancy that is achieved with a continuous treatment via osmotic minipumps ${ }^{23,31}$. Regarding other possible pharmacological targets against antipsychotic-induced catalepsy, the $5-\mathrm{HT}_{2 \mathrm{C}}$ receptor could be another candidate receptor that could be related to atypicality. Indeed, $5-\mathrm{HT}_{2 \mathrm{C}}$ antagonism is a common characteristic of atypical antipsychotic agents $^{34,35}$. A chronically administered dose of haloperidol at $1 \mathrm{mg} / \mathrm{kg} /$ day produces a catalepsy that may be reversed by a $5-\mathrm{HT}_{2 \mathrm{C}}$ antagonism ${ }^{9,10,35}$ and $5-\mathrm{HT}_{2 \mathrm{C}}$ antagonism may also reverse raclopride (a highly selective $D_{2 / 3}$ antagonist)-induced catalepsy ${ }^{36,37}$. In the Creed-Carson study described above, $5-\mathrm{HT}_{2 \mathrm{C}} \mathrm{R}$ antagonism was even superior to $5-\mathrm{HT}_{2 \mathrm{~A}} \mathrm{R}$ antagonism in reversing catalepsy induced by a single $0.5 \mathrm{mg} / \mathrm{kg}$ dose of haloperidol ${ }^{10}$. In a recent meta-regression study, $5-\mathrm{HT}_{2 \mathrm{C}} \mathrm{R}$ affinity of antipsychotic agents was inversely associated to the risk of EPS in clinical studies ${ }^{34}$. In light of these findings, a synergistic modulation of the nigrostriatal system by both $5-\mathrm{HT}_{2 \mathrm{~A}} \mathrm{R}$ and $5-\mathrm{HT}_{2 \mathrm{C}} \mathrm{R}$ may be hypothesized ${ }^{38}$. A $5-\mathrm{HT}_{2 \mathrm{~A}} \mathrm{R}$ antagonism may only be effective to prevent catalepsy within a limited range of $D_{2 / 3} R$ blockade ${ }^{39,40}$. Overall, these results suggest that a $5-\mathrm{HT}_{2 \mathrm{~A}} \mathrm{R}$ antagonism could-at least partiallymediate the clinically observed lower prevalence of acute extrapyramidal symptoms with atypical antipsychotic agents $^{3}$.

The second aspect of motor side effects evaluated in this study was haloperidol-induced VCM. In accordance with the literature ${ }^{11,22,23}$, our results demonstrate that a high occupancy of the striatal $\mathrm{D}_{2 / 3} \mathrm{R}$ (induced by haloperidol doses of 0.5 and $1 \mathrm{mg} / \mathrm{kg} /$ day) is associated with an induction of VCM. A $5-\mathrm{HT}_{2 \mathrm{~A}} \mathrm{R}$ antagonism failed to alleviate this side effect of haloperidol (both at 0.5 and $1 \mathrm{mg} / \mathrm{kg} /$ day). This finding is also in accordance with and extends the existing literature that, so far, has only evaluated the effect of $5-\mathrm{HT}_{2 \mathrm{~A}} \mathrm{R}$ antagonism on the VCM induced by the highest dose of haloperidol $(1 \mathrm{mg} / \mathrm{kg} /$ day $)$. Here, we extend this finding for a lower, but still supratherapeutic, dose of haloperidol $(0.5 \mathrm{mg} / \mathrm{kg} /$ day $)$. Interestingly, the effect of $5-\mathrm{HT}_{2 \mathrm{~A}} \mathrm{R}$ antagonism not only lacked any preventive effect on the VCM but was even associated with a tendency to increase haloperidolinduced VCM (Fig. 3d, not reaching significance). Consequently, $5-\mathrm{HT}_{2 \mathrm{~A}} \mathrm{R}$ antagonism is probably not implicated in the clinically and experimentally observed lower prevalence of VCM in animals treated with atypical vs. typical antipsychotics ${ }^{41-46}$ and other mechanisms might mediate this phenomenon. In this respect, $5-\mathrm{HT}_{2 \mathrm{C}} \mathrm{R}$ 
antagonism, which is a common feature of many atypical antipsychotics, has been proposed to play a role in the reduction of VCM in chronic haloperidol-treated rodents. One study in particular directly compared the effects of a selective $5-\mathrm{HT}_{2 \mathrm{C}}$ and $5-\mathrm{HT}_{2 \mathrm{~A}} \mathrm{R}$ antagonism in reversing haloperidol-induced VCM and found a superior efficacy of the former treatment ${ }^{10}$. Moreover, another study suggested a mechanistic link between this receptor and $\mathrm{VCM}^{47} \cdot 5-\mathrm{HT}_{2 \mathrm{C}} \mathrm{R}$ might thus be a more valid target of research for the prevention of antipsychotic-induced tardive dyskinesia. Finally, $5-\mathrm{HT}_{2 \mathrm{C}}$ antagonism, given its role in the regulation of dopaminergic neurotransmission, could be associated to properties of atypical antipsychotic drugs beyond motor side effects ${ }^{35,48,49}$.

\section{5- $\mathrm{HT}_{2 \mathrm{~A}} \mathrm{R}$ antagonism alters the dizocilpine-disruption of the PPI}

In the present study, our hypothesis was that adding a chronic antagonism at the $5-\mathrm{HT}_{2 \mathrm{~A}} \mathrm{R}$ to a chronic haloperidol treatment would allow to reverse the PPIdisruptive effect of dizocilpine. In this test, atypical antipsychotics have been found effective $\mathrm{e}^{50-55}$, while a haloperidol-only treatment has consistently been found ineffective $^{51,56}$ (with only one study, to our knowledge, showing efficacy of a 14-day haloperidol treatment at $1 \mathrm{mg} / \mathrm{kg} /$ day in mice ${ }^{54}$ ). Given that a $5-\mathrm{HT}_{2 \mathrm{~A}} \mathrm{R}$ antagonism alone has given positive results in one study ${ }^{18}$, one might consider that a chronic MDL-100,907 treatment could render the haloperidol treatment capable of reversing the effect of dizocilpine and thus provide evidence that a $5-\mathrm{HT}_{2 \mathrm{~A}} \mathrm{R}$ antagonism could be the substrate of the superiority of atypical agents over typical ones in this experimental paradigm. Our results showed a positive effect of MDL-100,907 on PPI, likely dependent on the concurrently administered dose of haloperidol. The absence of significant results in the post hoc tests may be explained by a lack of the necessary statistical power to clearly demonstrate significant differences in group-wise comparisons. Overall, the results of the PPI experiments provide further argument in favor of the efficacy of a $5-\mathrm{HT}_{2 \mathrm{~A}} \mathrm{R}$ antagonism in the reversal of dizocilpinedisruption of the PPI but further research is needed to confirm this result.

\section{$5-\mathrm{HT}_{2 \mathrm{~A}} \mathrm{R}$ antagonism fails to reverse the haloperidol- induced $D_{2 / 3}$ upregulation}

At a neurochemical level, chronic $D_{2 / 3} R$ antagonism by haloperidol led to a significant increase in the $D_{2 / 3} R$ binding in the $\mathrm{CP}$ and the NAc, an effect observed over the whole range of haloperidol doses. This is in accordance with the literature, in which a chronic $\mathrm{D}_{2 / 3} \mathrm{R}$ antagonism has been shown to upregulate striatal $D_{2 / 3} R^{22,23,57-61}$. The literature also suggests that this $\mathrm{D}_{2 / 3}$ upregulation is present to a lesser extent, if at all, with atypical antipsychotics, notably clozapine ${ }^{57,62-64}$. Given the affinity for the 5$\mathrm{HT}_{2 \mathrm{~A}} \mathrm{R}$ of the majority of atypical agents that were evaluated in these studies, it was proposed that a $5-\mathrm{HT}_{2 \mathrm{~A}} \mathrm{R}$ antagonism could prevent this $\mathrm{D}_{2 / 3} \mathrm{R}$ upregulation. To our knowledge, no study so far has assessed the effect of a 5$\mathrm{HT}_{2 \mathrm{~A}} \mathrm{R}$ antagonism on this phenomenon to directly test this hypothesis. In the present study, the co-administration of MDL-100,907 with any of the doses of haloperidol failed to significantly prevent haloperidol-induced $D_{2 / 3} R$ upregulation, suggesting that $5-\mathrm{HT}_{2 \mathrm{~A}} \mathrm{R}$ antagonism may not be implicated in the lack of $D_{2 / 3} R$ upregulation with atypical antipsychotics and other receptors could account for this phenomenon $^{22,23,57-61}$.

It is also hypothesized that haloperidol-induced $\mathrm{D}_{2 / 3} \mathrm{R}$ upregulation is implicated in the occurrence of $\mathrm{VCM}^{22}$. The results obtained here suggest that $D_{2 / 3} R$ upregulation is probably not a sufficient condition for the induction of VCM, as the animals treated with the 0.1 and the $0.25 \mathrm{mg} /$ $\mathrm{kg}$ /day doses presented a $D_{2 / 3} \mathrm{R}$ upregulation without VCM. These results challenge the hypothesized causal link between $\mathrm{D}_{2 / 3} \mathrm{R}$ upregulation and VCM induction and emphasize the need to conduct in-depth studies of these two phenomena.

\section{Haloperidol at moderate doses upregulates the $5-\mathrm{HT}_{2 \mathrm{~A}} \mathrm{R}$ in frontal cortical areas and the VTA}

A surprising finding of the present study was the increase in $5-\mathrm{HT}_{2 \mathrm{~A}} \mathrm{R}$ binding in frontal cortical areas and in the VTA, induced by a moderate dose of haloperidol $(0.25 \mathrm{mg} / \mathrm{kg} /$ day $)$. This effect was unaltered by $5-\mathrm{HT}_{2 \mathrm{~A}} \mathrm{R}$ antagonism. In fact, chronic $5-\mathrm{HT}_{2 \mathrm{~A}} \mathrm{R}$ antagonism was not associated with any change in either $D_{2 / 3} R$ or 5$\mathrm{HT}_{2 \mathrm{~A}} \mathrm{R}$ availabilities. This is a previously unappreciated finding, given that the literature so far has not assessed the effect of such a moderate dose of haloperidol on $5-\mathrm{HT}_{2 \mathrm{~A}} \mathrm{R}$ binding. Charron et al. ${ }^{65}$ showed that haloperidol, at $0.5 \mathrm{mg} / \mathrm{kg} /$ day decreases $\left[{ }^{3} \mathrm{H}\right]$ ketanserin binding in the frontal cortex and increases it in the striatum. However, this radiotracer also binds to $5-\mathrm{HT}_{2 \mathrm{C}} \mathrm{R}$, rendering the interpretation of these findings difficult. The downregulation of $5-\mathrm{HT}_{2 \mathrm{~A}} \mathrm{R}^{66-74}$, shared by atypical but not typical agents, was hypothesized as one of the substrates of atypicality, but no conclusive evidence linking it to the efficacy and side effect profile of atypical agents has been reported so far. The present study, given the absence of any $5-\mathrm{HT}_{2 \mathrm{~A}} \mathrm{R}$ antagonist properties of haloperidol, points to an indirect modulation of $5-\mathrm{HT}_{2 \mathrm{~A}} \mathrm{R}$ binding. One explanation for this could involve an alteration of serotonin release. If serotonin release is diminished, this transmitter would compete less with the $\left[{ }^{125} \mathrm{I}\right] \mathrm{R} 91150$ radiotracer for binding to the $5-\mathrm{HT}_{2 \mathrm{~A}} \mathrm{R}$, leading to an increase in radiotracer binding. Indeed, there is evidence that the dopaminergic system, via the $\mathrm{D}_{2}$ receptor, may alter serotonin transmission ${ }^{75-80}$. Previous studies 
showed that haloperidol treatment leads to a reduction in the concentration of a serotonin metabolite ${ }^{81}$ and serotonin itself in the brain ${ }^{82}$. Another possible hypothesis would be to attribute this haloperidol-induced change of $5-\mathrm{HT}_{2 \mathrm{~A}} \mathrm{R}$ binding to alterations in $\mathrm{D}_{2} / 5-\mathrm{HT}_{2 \mathrm{~A}}$ heteromers. Albizu et al. ${ }^{83}$ found that heteromers of $\mathrm{D}_{2} \mathrm{R}$ and 5$\mathrm{HT}_{2 \mathrm{~A}} \mathrm{R}$ produce allosteric modulations of the latter receptor via $D_{2}$-mediated mechanisms and alter its affinity for $5-\mathrm{HT}_{2 \mathrm{~A}} \mathrm{R}$-binding radioligands. Finally, to explain the differential effect of moderate vs. high doses of haloperidol on $5-\mathrm{HT}_{2 \mathrm{~A}} \mathrm{R}$ binding, one could hypothesize that low doses of haloperidol may preferentially act on $\mathrm{D}_{2}$ autoreceptors, while higher doses act both on auto- and hetero-receptors ${ }^{84}$.

Regarding the possible functional implications of this finding, previous data has highlighted a differential interaction between $5-\mathrm{HT}_{2 \mathrm{~A}} \mathrm{R}$-mediated and $\mathrm{D}_{2 / 3} \mathrm{R}$ mediated effects depending on the level of $\mathrm{D}_{2 / 3} \mathrm{R}$ occupancy. Indeed, Liegeois et al. ${ }^{40}$ and Bonaccorso et al. ${ }^{48}$ showed that in vivo $5-\mathrm{HT}_{2 \mathrm{~A}} \mathrm{R}$ blockade with MDL100,907 potentiated the dopamine-releasing effect of haloperidol in the rat medial prefrontal cortex, but only when haloperidol was administered at a dose lower or equal to $0.1 \mathrm{mg} / \mathrm{kg}$. This could possibly be explained by our finding that a similar dose of haloperidol alters 5$\mathrm{HT}_{2 \mathrm{~A}} \mathrm{R}$ binding in rat frontal cortical areas. From a functional perspective, this could provide a mechanism through which a relatively low $\mathrm{D}_{2 / 3} \mathrm{R}$ occupancy combined with a $5-\mathrm{HT}_{2 \mathrm{~A}} \mathrm{R}$ occupancy mediates the effect of atypical antipsychotics by relatively preserving dopaminergic transmission in the frontal cortex while potently blocking it in the mesolimbic system ${ }^{5}$. The marked expression of $5-\mathrm{HT}_{2 \mathrm{~A}} \mathrm{R}$ in prefrontal cortical neurons that project to the NAc and the VTA suggests that the haloperidol-induced $5-\mathrm{HT}_{2 \mathrm{~A}} \mathrm{R}$ upregulation might be relevant for the regulation of dopaminergic neurotransmission by antipsychotic medication ${ }^{85,86}$. Interestingly, in the present study, the dose of $0.25 \mathrm{mg} / \mathrm{kg} /$ day of haloperidol, is the dose at which the impact of $5-\mathrm{HT}_{2 \mathrm{~A}} \mathrm{R}$ antagonism shows the highest tendency towards a reversal of dizocilpine-disruption of PPI. 5- $\mathrm{HT}_{2 \mathrm{~A}} \mathrm{R}$ upregulation could be one of the mechanisms through which $5-\mathrm{HT}_{2 \mathrm{~A}} \mathrm{R}$ antagonism at this particular dose of haloperidol $(0.25 \mathrm{mg} / \mathrm{kg} /$ day $)$ may potentiate its efficacy on PPI. 5$\mathrm{HT}_{2 \mathrm{~A}} \mathrm{R}$ is also implicated in cognitive processes that may be deficient in patients suffering from schizophrenia and/ or who are treated with antipsychotic medication. This could be relevant to the haloperidol-induced $5-\mathrm{HT}_{2 \mathrm{~A}} \mathrm{R}$ upregulation $^{87}$. Nevertheless, further experiments, e.g. a cell-specific manipulation of $5-\mathrm{HT}_{2 \mathrm{~A}} \mathrm{R}$ signaling, are needed to directly interrogate the molecular underpinnings of the $\mathrm{D}_{2 / 3} \mathrm{R}$-occupancy-dependent $5-\mathrm{HT}_{2 \mathrm{~A}} \mathrm{R}$ alteration in $5-\mathrm{HT}_{2 \mathrm{~A}} \mathrm{R}$ binding and assess its functional implications in terms of possible behavioral effects.

\section{Limitations of the present study}

The use of a Mdr1a knock-out strain may be considered a limitation. We used this strain to be able to use $\left[{ }^{125} \mathrm{I}\right] \mathrm{R} 91150$ for the in-vivo imaging of 5$\mathrm{HT}_{2 \mathrm{~A}} \mathrm{R}^{14,88,89}$. The use of Mdr1a knock-out rats probably does not bias the behavioral and neurochemical responses to the chronic treatment with haloperidol and MDL-100,907, given that: (1) Mdr1a knock-out and wild-type rats present identical $\mathrm{D}_{2 / 3} \mathrm{R}$ and $5-\mathrm{HT}_{2 \mathrm{~A}} \mathrm{R}$ binding in the brain, as confirmed by ex-vivo autoradiography which is possible with $\left[{ }^{125} \mathrm{I}\right] \mathrm{R} 91150$ given the highest sensitivity of the autoradiography when compared to in-vivo SPECT, even in wild-type rats ${ }^{14,89}$, (2) the dose-occupancy curve of haloperidol measured here in Mdr1a knock-out is similar to that previously reported in wild-type rats $^{12,90}$, (3) the behavioral responses to haloperidol and dizocilpine were highly comparable to those observed in previous studies, notably the correspondence of the $D_{2 / 3} R$ occupancy by haloperidol and the induction of side effects ${ }^{8-12,22}$.

\section{Conclusion}

In conclusion, we provide evidence for the involvement of $5-\mathrm{HT}_{2 \mathrm{~A}} \mathrm{R}$ antagonism in the alleviation of catalepsy induced by haloperidol, an effect that is dose-dependent. Similarly, evidence is provided for an involvement of 5$\mathrm{HT}_{2 \mathrm{~A}} \mathrm{R}$ antagonism on the reversal of dizocilpinedisruption of PPI. 5- $\mathrm{HT}_{2 \mathrm{~A}} \mathrm{R}$ antagonism failed to prevent the upregulation of $\mathrm{D}_{2 / 3} \mathrm{R}$ that is induced by chronic haloperidol treatment, as well as the induction of VCM by high doses of this typical antipsychotic agent. A previously unappreciated dose-dependent effect of moderate doses of haloperidol on the in-vivo frontal cortical $5-\mathrm{HT}_{2 \mathrm{~A}} \mathrm{R}$ binding has also been observed. The present work points to an involvement of a $5-\mathrm{HT}_{2 \mathrm{~A}} \mathrm{R}$ antagonism in the modification of some aspects of the efficacy and side effect profile of haloperidol, suggesting that, at least partially, 5$\mathrm{HT}_{2 \mathrm{~A}} \mathrm{R}$ antagonism might be associated with atypicality. Based on the results of this study however, the role of the $5-\mathrm{HT}_{2 \mathrm{~A}} \mathrm{R}$ antagonism as the sole (or even the major) determinant of antipsychotic atypicality can probably be rejected. The need to carefully choose clinically relevant antipsychotic doses (i.e. a dose of $0.5 \mathrm{mg} / \mathrm{kg} /$ day and not $1 \mathrm{mg} / \mathrm{kg} /$ day) and to further investigate the role of neurochemical changes induced by chronic antipsychotic treatment in the search for causal relationships with its clinical effect is warranted.

\section{Acknowledgements}

This work was supported by the Swiss National Science Foundation (grant no. 310030_156829), the Geneva Neuroscience Centre, the Maria Zaousi Foundation (Greece), the "Swiss Association for Alzheimer's Research" and the Vachoux Foundation (Switzerland). Authors are grateful to Mrs. Maria Surini-Demiri and Mr. Marouane Ben Ammar for excellent technical assistance. 


\section{Author details}

${ }^{1}$ Division of Adult Psychiatry, Department of Psychiatry, Geneva University Hospitals, Geneva, Switzerland. 'Division of Psychiatric Specialties, Department of Psychiatry, Geneva University Hospitals, Geneva, Switzerland. ${ }^{3}$ Department of Psychiatry, Faculty of Medicine, University of Geneva, Geneva, Switzerland. ${ }^{4}$ Department of Basic Neurosciences, Faculty of Medicine, University of Geneva, Geneva, Switzerland

\section{Conflict of interest}

The authors declare that they have no conflict of interest.

\section{Publisher's note}

Springer Nature remains neutral with regard to jurisdictional claims in published maps and institutional affiliations.

Supplementary Information accompanies this paper at (https://doi.org/ 10.1038/s41398-020-01179-5).

Received: 25 July 2020 Revised: 15 December 2020 Accepted: 16 December 2020

Published online: 14 January 2021

\section{References}

1. Ginovart, N. \& Kapur, S. Role of dopamine $D(2)$ receptors for antipsychotic activity. Handb. Exp. Pharmacol. 212, 27-52 (2012).

2. Kapur, S. \& Remington, G. Dopamine $D(2)$ receptors and their role in atypical antipsychotic action: still necessary and may even be sufficient. Biol. Psychiatry 50, 873-883 (2001).

3. Martino, D., Karnik, V., Osland, S., Barnes, T. R. E. \& Pringsheim, T. M. Movement disorders associated with antipsychotic medication in people with schizophrenia: an overview of cochrane reviews and meta-analysis. Can. J. Psychiatry Rev. Can. Psychiatr. 63, 706743718777392 (2018).

4. Leucht, S. et al. Comparative efficacy and tolerability of 15 antipsychotic drugs in schizophrenia: a multiple-treatments meta-analysis. Lancet 382, 951-962 (2013).

5. Meltzer, H. Y. What's atypical about atypical antipsychotic drugs? Curr. Opin Pharmacol. 4, 53-57 (2004).

6. Ebdrup, B. H., Rasmussen, H., Arnt, J. \& Glenthoj, B. Serotonin 2A receptor antagonists for treatment of schizophrenia. Expert Opin. Investig. Drugs 20, 1211-1223 (2011).

7. Kapur, S., Wadenberg, M. L. \& Remington, G. Are animal studies of antipsychotics appropriately dosed? Lessons from the bedside to the bench. Can. J. Psychiatry Rev. Can. Psychiatr. 45, 241-246 (2000).

8. McOmish, C. E., Lira, A., Hanks, J. B. \& Gingrich, J. A. Clozapine-induced locomotor suppression is mediated by 5 -HT2A receptors in the forebrain. $\mathrm{Neu}$ ropsychopharmacology 37, 2747-2755 (2012).

9. Reavill, C., Kettle, A., Holland, V., Riley, G. \& Blackburn, T. P. Attenuation of haloperidol-induced catalepsy by a $5-\mathrm{HT} 2 \mathrm{C}$ receptor antagonist. $\mathrm{Br}$. J. Pharmacol. 126, 572-574 (1999).

10. Creed-Carson, M., Oraha, A. \& Nobrega, J. N. Effects of 5-HT(2A) and 5-HT(2C) receptor antagonists on acute and chronic dyskinetic effects induced by haloperidol in rats. Behav. Brain Res. 219, 273-279 (2011).

11. Karl, T., Duffy, L., O'Brien, E., Matsumoto, I. \& Dedova, I. Behavioural effects of chronic haloperidol and risperidone treatment in rats. Behav. Brain Res. 171 286-294 (2006).

12. Wadenberg, M. L., Soliman, A., VanderSpek, S. C. \& Kapur, S. Dopamine D(2) receptor occupancy is a common mechanism underlying animal models of antipsychotics and their clinical effects. Neuropsychopharmacology $\mathbf{2 5}$ 633-641 (2001).

13. Tsartsalis, S. et al. Dual-radiotracer translational SPECT neuroimaging. Comparison of three methods for the simultaneous brain imaging of D2/3 and 5HT2A receptors. Neuroimage 176, 528-540 (2018).

14. Dumas, N. et al. In vivo quantification of 5-HT2A brain receptors in Mdr1a KO rats with 123I-R91150 single-photon emission computed tomography. Mol. Imaging 14, https://doi.org/10.2310/7290.2015.00006 (2015).

15. Tsartsalis, S. et al. A single-scan protocol for absolute D2/3 receptor quantification with [123|]|BZM SPECT. Neurolmage 147, 461-472 (2017).
16. Swerdlow, N. R., Weber, M., Qu, Y., Light, G. A. \& Braff, D. L. Realistic expectations of prepulse inhibition in translational models for schizophrenia research. Psychopharmacology 199, 331-388 (2008).

17. Wadenberg, M. G., Sills, T. L., Fletcher, P. J. \& Kapur, S. Antipsychoticlike effects of amoxapine, without catalepsy, using the prepulse inhibition of the acoustic startle reflex test in rats. Biol. Psychiatry 47, 670-676 (2000).

18. Varty, G. B., Bakshi, V. P. \& Geyer, M. A. M100907, a serotonin 5-HT2A receptor antagonist and putative antipsychotic, blocks dizocilpine-induced prepulse inhibition deficits in Sprague-Dawley and Wistar rats. Neuropsychopharmacology 20, 311-321 (1999).

19. Tournier, B. B. \& Ginovart, N. Repeated but not acute treatment with (9)tetrahydrocannabinol disrupts prepulse inhibition of the acoustic startle: reversal by the dopamine $\mathrm{D}(2) /(3)$ receptor antagonist haloperidol. Eur. Neuropsychopharmacol. 24, 1415-1423 (2014).

20. Martinez, Z. A., Oostwegel, J., Geyer, M. A., Ellison, G. D. \& Swerdlow, N. R. "Early" and "late" effects of sustained haloperidol on apomorphine- and phencyclidine-induced sensorimotor gating deficits. Neuropsychopharmacology 23, 517-527 (2000).

21. Gobira, P. H., Ropke, J., Aguiar, D. C., Crippa, J. A. \& Moreira, F. A. Animal models for predicting the efficacy and side effects of antipsychotic drugs. Rev. Bras. Psiquiatr. 35, S132-S139 (2013).

22. Turrone, P., Remington, G., Kapur, S. \& Nobrega, J. N. The relationship between dopamine D2 receptor occupancy and the vacuous chewing movement syndrome in rats. Psychopharmacology 165, 166-171 (2003).

23. Turrone, P., Remington, G., Kapur, S. \& Nobrega, J. N. Differential effects of within-day continuous vs. transient dopamine D2 receptor occupancy in the development of vacuous chewing movements (VCMs) in rats. Neuropsychopharmacology 28, 1433-1439 (2003).

24. Glenthoj, B. Persistent vacuous chewing in rats following neuroleptic treatment: relationship to dopaminergic and cholinergic function. Psychopharmacology 113, 157-166 (1993).

25. Crowley, J. J. et al. Antipsychotic-induced vacuous chewing movements and extrapyramidal side effects are highly heritable in mice. Pharmacogenom. J. 12 , 147-155 (2012).

26. Schiffer, W. K. et al. Serial microPET measures of the metabolic reaction to a microdialysis probe implant. J. Neurosci. Methods 155, 272-284 (2006).

27. Altman, D. G. Practical Statistics for Medical Research (Chapman and Hall, 2020).

28. Vallez Garcia, D. et al. A standardized method for the construction of tracer specific PET and SPECT rat brain templates: validation and implementation of a toolbox. PLOS ONE 10, e0122363 (2015).

29. Bennett, C. M., Wolford, G. L. \& Miller, M. B. The principled control of false positives in neuroimaging. Soc. Cogn. Affect. Neurosci. 4, 417-422 (2009).

30. Tsartsalis, S. et al. Dynamic image denoising for voxel-wise quantification with Statistical Parametric Mapping in molecular neuroimaging. PLOS ONE 13, e0203589 (2018).

31. Ginovart, N., Wilson, A. A., Hussey, D., Houle, S. \& Kapur, S. D2-receptor upregulation is dependent upon temporal course of D2-occupancy: a longitudinal [11C]-raclopride PET study in cats. Neuropsychopharmacology 34, 662-671 (2008).

32. Mombereau, C., Arnt, J. \& Mork, A. Involvement of presynaptic 5-HT1A receptors in the low propensity of brexpiprazole to induce extrapyramidal side effects in rats. Pharmacol. Biochem. Behav. 153, 141-146 (2017).

33. Osborne, P. G., O'Connor, W. T., Beck, O. \& Ungerstedt, U. Acute versus chronic haloperidol: relationship between tolerance to catalepsy and striatal and accumbens dopamine, GABA and acetylcholine release. Brain Res. 634, 20-30 (1994).

34. Olten, B. \& Bloch, M. H. Meta regression: Relationship between antipsychotic receptor binding profiles and side-effects. Prog. Neuro-Psychopharmacol. Biol. Psychiatry 84, 272-281 (2018).

35. Di Giovanni, G. \& De Deurwaerdere, P. New therapeutic opportunities for 5HT2C receptor ligands in neuropsychiatric disorders. Pharmacol. Ther. 157, 125-162 (2016)

36. Wadenberg, M. L. \& Ahlenius, S. Antagonism by the 5-HT2A/C receptor agonist DOl of raclopride-induced catalepsy in the rat. Eur. J. Pharmacol. 294 247-251 (1995).

37. Wadenberg, M. G., Browning, J. L., Young, K. A. \& Hicks, P. B. Antagonism at 5$\mathrm{HT}(2 \mathrm{~A})$ receptors potentiates the effect of haloperidol in a conditioned avoidance response task in rats. Pharmacol. Biochem. Behav. 68, 363-370 (2001). 
38. Egerton, A., Ahmad, R., Hirani, E. \& Grasby, P. M. Modulation of striatal dopamine release by 5-HT2A and 5-HT2C receptor antagonists: [11C]raclopride PEI studies in the rat. Psychopharmacology 200, 487-496 (2008).

39. Lucas, G., De Deurwaerdere, P., Caccia, S. \& Umberto, S. The effect of serotonergic agents on haloperidol-induced striatal dopamine release in vivo: opposite role of 5-HT(2A) and 5-HT(2C) receptor subtypes and significance of the haloperidol dose used. Neuropharmacology 39, 1053-1063 (2000).

40. Liegeois, J. F., Ichikawa, J. \& Meltzer, H. Y. 5-HT(2A) receptor antagonism potentiates haloperidol-induced dopamine release in rat medial prefrontal cortex and inhibits that in the nucleus accumbens in a dose-dependent manner. Brain Res. 947, 157-165 (2002).

41. Carbon, M., Kane, J. M., Leucht, S. \& Correll, C. U. Tardive dyskinesia risk with first- and second-generation antipsychotics in comparative randomized controlled trials: a meta-analysis. World Psychiatry 17, 330-340 (2018).

42. Marchese, G. et al. Haloperidol versus risperidone on rat "early onset" vacuous chewing. Behav. Brain Res. 149, 9-16 (2004).

43. Ikeda, $\mathrm{H}$. et al. Effects of chronic haloperidol and clozapine on vacuous chewing and dopamine-mediated jaw movements in rats: evaluation of a revised animal model of tardive dyskinesia. J. Neural Transm. 106, 1205-1216 (1999).

44. Egan, M. F., Hyde, T. M., Kleinman, J. E. \& Wyatt, R. J. Neuroleptic-induced vacuous chewing movements in rodents: incidence and effects of long-term increases in haloperidol dose. Psychopharmacology 117, 74-81 (1995).

45. Naidu, P. S. \& Kulkarni, S. K. Effect of 5-HT1A and 5-HT2A/2C receptor modulation on neuroleptic-induced vacuous chewing movements. Eur. J. Pharmacol. 428, 81-86 (2001).

46. Rosengarten, H. \& Quartermain, D. The effect of chronic treatment with typical and atypical antipsychotics on working memory and jaw movements in three- and eighteen-month-old rats. Prog. Neuro-Psychopharmacol. Biol. Psychiatry 26, 1047-1054 (2002).

47. Wolf, W. A., Bieganski, G. J., Guillen, V. \& Mignon, L. Enhanced 5-HT2C receptor signaling is associated with haloperidol-induced "early onset" vacuous chewing in rats: implications for antipsychotic drug therapy. Psychopharmacology 182, 84-94 (2005).

48. Bonaccorso, S. et al. SR46349-B, a 5-HT(2A/2C) receptor antagonist, potentiates haloperidol-induced dopamine release in rat medial prefrontal cortex and nucleus accumbens. Neuropsychopharmacology 27, 430-441 (2002).

49. Di Matteo, V., Cacchio, M., Di Giulio, C. \& Esposito, E. Role of serotonin(2C) receptors in the control of brain dopaminergic function. Pharmacol. Biochem. Behav. 71, 727-734 (2002).

50. Bubenikova, V., Votava, M., Horacek, J., Palenicek, T. \& Dockery, C. The effect of zotepine, risperidone, clozapine and olanzapine on MK-801-disrupted sensorimotor gating. Pharmacol. Biochem. Behav. 80, 591-596 (2005).

51. Varty, G. B. \& Higgins, G. A. Examination of drug-induced and isolation-induced disruptions of prepulse inhibition as models to screen antipsychotic drugs. Psychopharmacology 122, 15-26 (1995).

52. Zangrando, J. et al. Atypical antipsychotic olanzapine reversed deficit on prepulse inhibition of the acoustic startle reflex produced by microinjection of dizocilpine (MK-801) into the inferior colliculus in rats. Behav. Brain Res. 257, 77-82 (2013).

53. Hudson, M. R., Rind, G., O'Brien, T. J. \& Jones, N. C. Reversal of evoked gamma oscillation deficits is predictive of antipsychotic activity with a unique profile for clozapine. Transl. Psychiatry 6, e784 (2016).

54. Li, C. et al. Sub-chronic antipsychotic drug administration reverses the expression of neuregulin 1 and ErbB4 in a cultured MK801-induced mouse primary hippocampal neuron or a neurodevelopmental schizophrenia model. Neurochem. Res. 41, 2049-2064 (2016).

55. Fijal, K., Popik, P. \& Nikiforuk, A. Co-administration of 5-HT6 receptor antagonists with clozapine, risperidone, and a 5-HT2A receptor antagonist: effects on prepulse inhibition in rats. Psychopharmacology 231, 269-281 (2014).

56. Feifel, D. \& Priebe, K. The effects of subchronic haloperidol on intact and dizocilpine-disrupted sensorimotor gating. Psychopharmacology 146, 175-179 (1999).

57. Kusumi, I., Takahashi, Y., Suzuki, K., Kameda, K. \& Koyama, T. Differential effects of subchronic treatments with atypical antipsychotic drugs on dopamine D2 and serotonin 5-HT2A receptors in the rat brain. J. Neural Transm. 107, 295-302 (2000)

58. Ishikane, T., Kusumi, I., Matsubara, R., Matsubara, S. \& Koyama, T. Effects of serotonergic agents on the up-regulation of dopamine D2 receptors induced by haloperidol in rat striatum. Eur. J. Pharmacol. 321, 163-169 (1997).
59. Varela, F. A. et al. Repeated aripiprazole treatment causes dopamine D2 receptor up-regulation and dopamine supersensitivity in young rats. J. Psychopharmacol. 28, 376-386 (2014).

60. Inoue, A. et al. Aripiprazole, a novel antipsychotic drug, inhibits quinpiroleevoked GTPase activity but does not up-regulate dopamine D2 receptor following repeated treatment in the rat striatum. Eur. J. Pharmacol. 321, 105-111 (1997).

61. Mahmoudi, S., Levesque, D. \& Blanchet, P. J. Upregulation of dopamine D3, not D2, receptors correlates with tardive dyskinesia in a primate model. Mov. Disord. 29, 1125-1133 (2014).

62. Tarazi, F. I., Yeghiayan, S. K., Baldessarini, R. J., Kula, N. S. \& Neumeyer, J. L. Longterm effects of $\mathrm{S}(+) \mathrm{N}$-n-propylnorapomorphine compared with typical and atypical antipsychotics: differential increases of cerebrocortical D2-like and striatolimbic D4-like dopamine receptors. Neuropsychopharmacology 17 186-196 (1997).

63. Tarazi, F. I., Florijn, W. J. \& Creese, I. Differential regulation of dopamine receptors after chronic typical and atypical antipsychotic drug treatment. Neuroscience 78, 985-996 (1997).

64. Lidow, M. S. \& Goldman-Rakic, P. S. A common action of clozapine, haloperidol, and remoxipride on D1- and D2-dopaminergic receptors in the primate cerebral cortex. Proc. Natl Acad. Sci. USA 91, 4353-4356 (1994).

65. Charron, A., Hage, C. E., Servonnet, A. \& Samaha, A.-N. 5-HT2 receptors modulate the expression of antipsychotic-induced dopamine supersensitivity. Eur. Neuropsychopharmacol. 25, 2381-2393 (2015).

66. Amato, D., Natesan, S., Yavich, L., Kapur, S. \& Muller, C. P. Dynamic regulation of dopamine and serotonin responses to salient stimuli during chronic haloperidol treatment. Int. J. Neuropsychopharmacol. 14, 1327-1339 (2011).

67. Yadav, P. N., Kroeze, W. K., Farrell, M. S. \& Roth, B. L. Antagonist functional selectivity: 5-HT2A serotonin receptor antagonists differentially regulate 5HT2A receptor protein level in vivo. J. Pharmacol. Exp. Ther. 339, 99-105 (2011).

68. Lian, J., Huang, X.-F., Pai, N. \& Deng, C. Effects of olanzapine and betahistine cotreatment on serotonin transporter, 5-HT2A and dopamine D2 receptor binding density. Prog. Neuro-Psychopharmacol. Biol. Psychiatry 47, 62-68 (2013).

69. Moreno, J. L. et al. Persistent effects of chronic clozapine on the cellular and behavioral responses to LSD in mice. Psychopharmacology 225, 217-226 (2013).

70. Tarazi, F. I., Zhang, K. \& Baldessarini, R. J. Long-term effects of olanzapine, risperidone, and quetiapine on serotonin $1 \mathrm{~A}, 2 \mathrm{~A}$ and $2 \mathrm{C}$ receptors in rat forebrain regions. Psychopharmacology 161, 263-270 (2002).

71. Steward, L. J., Kennedy, M. D., Morris, B. J. \& Pratt, J. A. The atypical antipsychotic drug clozapine enhances chronic PCP-induced regulation of prefrontal cortex 5-HT2A receptors. Neuropharmacology 47, 527-537 (2004).

72. Choi, Y. K., Adham, N., Kiss, B., Gyertyan, I. \& Tarazi, F. I. Long-term effects of aripiprazole exposure on monoaminergic and glutamatergic receptor subtypes: comparison with cariprazine. CNS Spectr. 22, 1-11 (2017).

73. Kurita, M. et al. HDAC2 regulates atypical antipsychotic responses through the modulation of mGlu2 promoter activity. Nat. Neurosci. 15, 1245-1254 (2012).

74. Huang, X.-F., Tan, Y. Y., Huang, X. \& Wang, Q. Effect of chronic treatment with clozapine and haloperidol on $5-\mathrm{HT} 2 \mathrm{~A}$ and $2 \mathrm{C}$ receptor mRNA expression in the rat brain. Neurosci. Res. 59, 314-321 (2007).

75. Mendlin, A., Martin, F. J. \& Jacobs, B. L. Involvement of dopamine D2 receptors in apomorphine-induced facilitation of forebrain serotonin output. Eur. J. Pharmacol. 351, 291-298 (1998).

76. Amargos-Bosch, M., Adell, A. \& Artigas, F. Antipsychotic drugs reverse the AMPA receptor-stimulated release of $5-\mathrm{HT}$ in the medial prefrontal cortex. $J$. Neurochem. 102, 550-561 (2007).

77. Amargos-Bosch, M., Lopez-Gil, X., Artigas, F. \& Adell, A. Clozapine and olanzapine, but not haloperidol, suppress serotonin efflux in the medial prefrontal cortex elicited by phencyclidine and ketamine. Int. J. Neuropsychopharmacol. 9, 565-573 (2006).

78. Amargós-Bosch, M., Adell, A., Bortolozzi, A. \& Artigas, F. Stimulation of a1adrenoceptors in the rat medial prefrontal cortex increases the local in vivo 5hydroxytryptamine release: reversal by antipsychotic drugs. J. Neurochem. 87, 831-842 (2004).

79. Amargos-Bosch, M., Adell, A., Bortolozzi, A. \& Artigas, F. Stimulation of alpha1adrenoceptors in the rat medial prefrontal cortex increases the local in vivo 5hydroxytryptamine release: reversal by antipsychotic drugs. J. Neurochem. 87, 831-842 (2003).

80. Maejima, T., Masseck, O. A., Mark, M. D. \& Herlitze, S. Modulation of firing and synaptic transmission of serotonergic neurons by intrinsic $\mathrm{G}$ protein-coupled receptors and ion channels. Front. Integr. Neurosci. 7, 40 (2013). 
81. Burnet, P. W., Chen, C. P., McGowan, S., Franklin, M. \& Harrison, P. J. The effects of clozapine and haloperidol on serotonin-1A, $-2 \mathrm{~A}$ and $-2 \mathrm{C}$ receptor gene expression and serotonin metabolism in the rat forebrain. Neuroscience $\mathbf{7 3}$, 531-540 (1996)

82. Bishnoi, M., Chopra, K. \& Kulkarni, S. K. Neurochemical changes associated with chronic administration of typical antipsychotics and its relationship with tardive dyskinesia. Methods Find. Exp. Clin. Pharmacol. 29, 211-216 (2007).

83. Albizu, L., Holloway, T., Gonzalez-Maeso, J. \& Sealfon, S. C. Functional crosstalk and heteromerization of serotonin 5-HT2A and dopamine D2 receptors. Neuropharmacology 61, 770-777 (2011).

84. Dias, F. R. C., de Matos, L. W., Sampaio, M. D. F. D. S., Carey, R. J. \& Carrera, M. P. Opposite effects of low versus high dose haloperidol treatments on spontaneous and apomorphine induced motor behavior: evidence that at a very low dose haloperidol acts as an indirect dopamine agonist. Behav. Brain Res. 229, 153-159 (2012).

85. Mocci, G., Jiménez-Sánchez, L., Adell, A., Cortés, R. \& Artigas, F. Expression of 5HT2A receptors in prefrontal cortex pyramidal neurons projecting to nucleus accumbens. Potential relevance for atypical antipsychotic action. Neuropharmacology 79, 49-58 (2014).

86. Vazquez-Borsetti, P., Cortes, R. \& Artigas, F. Pyramidal neurons in rat prefrontal cortex projecting to ventral tegmental area and dorsal raphe nucleus express 5-HT2A receptors. Cereb. Cortex 19, 1678-1686 (2008).

87. Williams, G. V., Rao, S. G. \& Goldman-Rakic, P. S. The physiological role of 5HT2A receptors in working memory. J. Neurosci. 22, 2843-2854 (2002).

88. Dumas, N. et al. Small-animal single-photon emission computed tomographic imaging of the brain serotoninergic systems in wild-type and mdr1a knockout rats. Mol. Imaging 13, https://doi.org/10.2310/7290.2013.00072 (2014).

89. Tsartsalis, S. et al. 5-HT2A receptor SPECT imaging with [(1)(2)(3)I]R91150 under P-gp inhibition with tariquidar: more is better? Nucl. Med. Biol. 43, 81-88 (2016).

90. Natesan, S., Reckless, G. E., Nobrega, J. N., Fletcher, P. J. \& Kapur, S. Dissociation between in vivo occupancy and functional antagonism of dopamine D2 receptors: comparing aripiprazole to other antipsychotics in animal models. Neuropsychopharmacology 31, 1854-1863 (2005). 